\title{
DISTRIBUTION OF PERMAFROST IN FINLAND
}

\author{
MATTI SEPPÄLÄ
}

SEPPÄLÄ, M. 1997. Distribution of permafrost in Finland. Bull. Geol. Soc. Finland 69, Part 1-2, 87-96.

Two main types of permafrost are found in northern Finland. The most widely known occurence is in mires, in peat mounds with permanently frozen cores known as palsas. Some fully new, small occurrences have been found in pounus, small peat humps over large areas in Lapland. The second main type of permafrost occurrence is located above the tree line on barren fell summits there permafrost means continuous temperature below $0^{\circ} \mathrm{C}$ in the bedrock. Some massive cave ice has been found in Lapland, too. The climatic conditions at permafrost sites are still poorly know because the local topography affects the temperature conditions. Only sporadic recordings are available from the summits of fells and from palsa mires. In general, the mean annual air temperature for permafrost formation should be below $-1^{\circ} \mathrm{C}$. Snow depth seems to be the most critical factor for permafrost formation in Lapland: thin snow cover promotes frost penetration. Vegetation provides a useful indicator of snow depth and of possible permafrost sites. Some proposals are made for permafrost studies in Lapland.

Keywords: periglacial features, permafrost, palsas, mires, bedrock, climate, topography, snow, soils, vegetation, Lapland, Finland

Matti Seppälä, Laboratory of Physical Geography, P.O. Box 9, FIN-00014 Helsinki University, Finland

\section{INTRODUCTION}

Northern Finland is located in the zone of discontinuous permafrost with annual mean temperature overall just below $0^{\circ} \mathrm{C}$. The existence of permafrost in palsa cores in Lapland is widely known (e.g. Seppälä 1988). Other direct observations of permafrost are rare because underground construction is seldom undertaken in the highlands and ground temperatures are mainly measured in valleys in the forest zone. Frost studies by the Finnish authorities have concentrated on seasonal frost (e.g. Soveri \& Varjo 1977), which is of major practical consequence for human life. During the last 15 years our knowledge of permafrost distribution in northern Fennoscandia has increased significantly (e.g. King 1982, 1983, 1984; King \& Seppälä 1987, 1988; Kejonen et al 1991). 
The main tasks of this presentation are

- to present a short review of permafrost distribution in Finland

- to discuss the environments in Lapland in which permafrost can be expected

- to suggest why permafrost is formed in these places

- to make proposals for further permafrost studies.

\section{DISTRIBUTION OF PERMAFROST}

\section{Permafrost in mires}

Palsas with permafrost cores are located in valleys and low depressions with peat deposits. The basic factor for the survival of frost in palsas is the good insulating property of dry peat. The thermoconductivity of wet and frozen peat is much higher. Cold can penetrate deep into the saturated and frozen peat and the surface layer of the peat then dries very fast in the early spring and summer and protects the frozen core of the palsa mound against thawing. Even though daily air temperatures are sometimes high $\left(+30^{\circ} \mathrm{C}\right)$ in the far north $\left(68^{\circ} \mathrm{N}\right.$ latitude), the summer is too short to thaw the frozen core of palsas.

The southern limit of the main palsa region (Fig. 1) follows the north shore of Lake Inari towards eastern Enontekiö and extends west, crossing the border between Sweden and Finland at about $68^{\circ} 25^{\prime} \mathrm{N}$ latitude. North of this limit there are hundreds of palsas mires. The largest ones have been marked on the general geomorphological map of Finland (Fogelberg \& Seppälä 1978). Mires with palsas are mainly treeless, though single small birches sometimes grow on palsa edges. In Finland, pine and spruce do not like to grow on permafrost, though in both in Canada and Siberia conifers establish on permafrost. The thickness of the peat in palsa mires is at least one metre and often more than two. Palsas need a certain minimum thickness of insulating peat in order to form, and the thickness depends on the thickness of the active layer in local climatic conditions (Seppälä 1988: 269). At the end of the thawing season (October-No- vember), the active layer on palsas is seldom more than $70 \mathrm{~cm}$ in Finnish Lapland (Seppälä 1976, $1982 \mathrm{~b}, 1983)$. Some palsas have just a thin $0.5-1$ $\mathrm{m}$ peat layer and their core is mainly formed of frozen silt or silty till. These are known as mineral-cored palsas, which probably are transitional forms to mineral frost mounds without peat cover. The last mentioned have not so far been found in Finnish Lapland (cf. Åhman 1977).

Palsas in Finnish Lapland rise up to $7 \mathrm{~m}$ above the surrounding mire surface and their frozen cores reach about the same depth into the mire as they extend above the surface. If the palsa is $3 \mathrm{~m}$ high the total thickness of the frozen core is at least 5-6 m. We do not know exactly how deep the permafrost extends into the mineral soil beneath the palsas. Small, developing palsas have not yet reached the mineral soil at the bottom of the mire.

In September 1996, obaservation was made of new permafrost formation at the edge of a palsa mire in Utsjoki. Some of the pounus (small peat mounds less than $1 \mathrm{~m}$ in height) had a frozen core about $50 \mathrm{~cm}$ in thickness which had been in place for two years. This is evidence of the new permafrost formation that occasionally occurs in northernmost Lapland. Small palsa embryos were formed in the same mire during the winter 1984-85 when the snow layer was less than $30 \mathrm{~cm}$ thick in February and temperatures were low (Seppälä 1990). Under natural conditions the frost then penetrated deeper than $70 \mathrm{~cm}$ in the peat layers, and this is sufficient for the formation of small frost lens and the initiation of palsa formation (Seppälä 1990: 201).

It is not unusual to find a frozen layer in the strings of aapa mires in the middle of summer, and this type of observation has led some to conclude, wrongly, that string bogs begin as permafrost formations (Schenk 1966, 1970). Also late autumn frost has been observed in strings, for example in Kittilä, but systematic follow-up observations have been carried out. Observations of Seppälä and Koutaniemi (1985) in Kuusamo, south of the Arctic Circle, showed that the frost did not stay unmelted year-round. It is not impossible that deep frost layers could be formed in strings during 


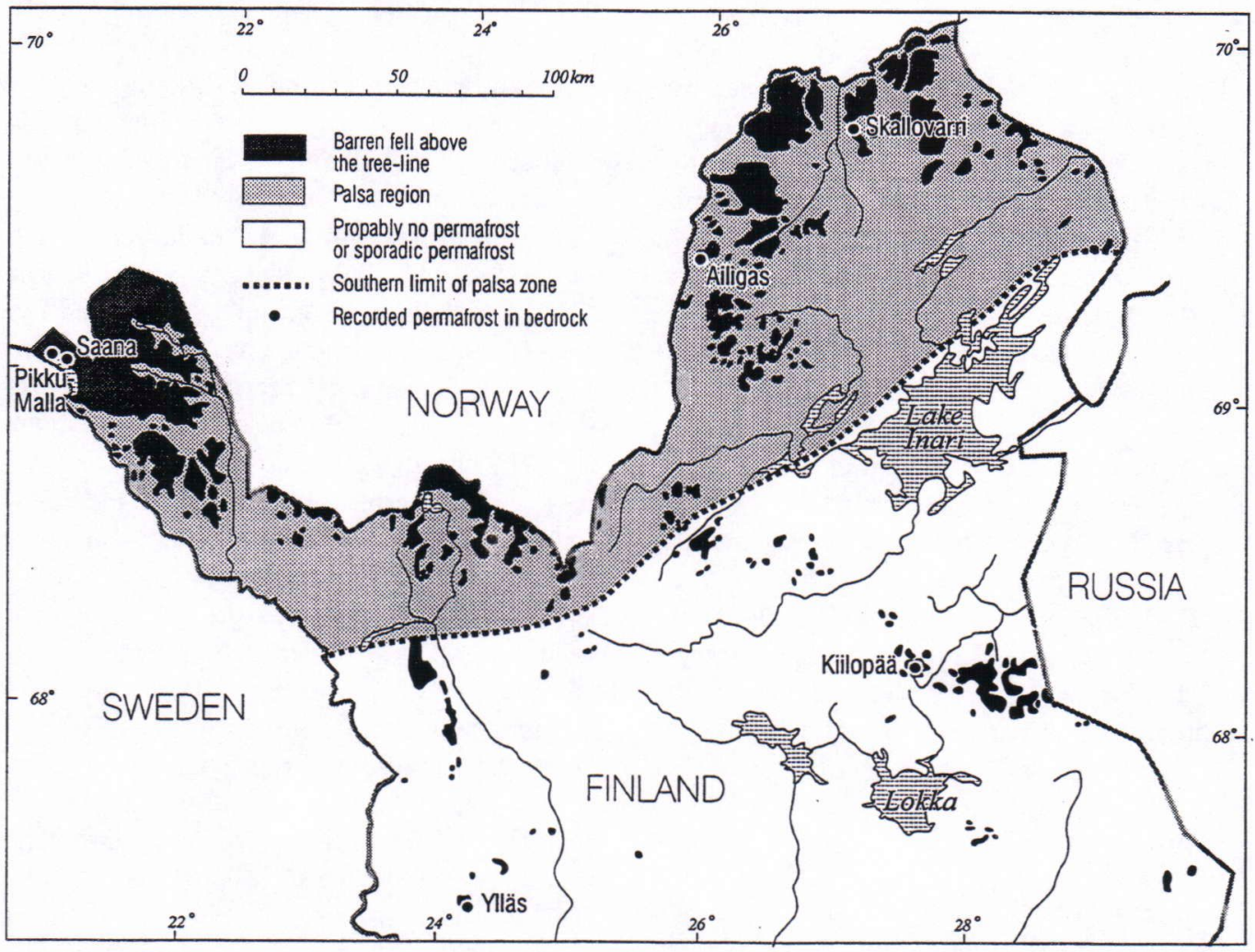

Fig. 1. Potential permafrost locations in northern Finland. Barren fell summits (dark grey) partly after the map Forests of Lapland (Atlas of Finland Folio 141: 5, Vegetation and flora). Sites where permafrost has been recorded in the bedrock are indicated with a dot and named (King \& Seppälä 1987). The palsa zone, where palsas occur in many mires, is indicated in grey (Seppälä 1988).

a cold winter with thin snow cover. This frost could even last several years but then only in the strings not in the pools.

Hänninen (1995) discovered a layer of frost 30 $\mathrm{cm}$ thick about $1 \mathrm{~m}$ below the surface of a Sphagnum mound (1 m high) in Koivulampi mire, Pudasjärvi $\left(65^{\circ} 15^{\prime} \mathrm{N}, 27^{\circ} \mathrm{E}\right)$ on 18 October, 1994 . The peat mound had earlier been frozen for several years, but melted totally in 1989. New permafrost formed again in winter 1993-94. This observation was made some $250 \mathrm{~km}$ south of Ylläs (Fig. 1), which until that time was the southernmost permafrost site recorded in Finland.

\section{Permafrost in bedrock}

Geoelectrical soundings gave us a tool to observe permafrost deep in the bedrock (King \& Seppälä 1987, 1988). Previously unknown permafrost $10-50 \mathrm{~m}$ in thickness was recorded in several summit areas of fells above the timber line. In many localities at higher elevations thickness of the permafrost is at least $50 \mathrm{~m}$ and a thickness of more than $100 \mathrm{~m}$ may be extrapolated for the highest mountains, such as Mt. Saana at Kilpisjärvi (Fig. 1). 
Permafrost in bedrock means only that the temperature remains continuously below zero degrees centigrade. This was explicitly observed on the fell summit of Ylläs in a well drilled by the Finnish Broadcasting Co. The well was frozen at $40 \mathrm{~m}$ depth below the surface (King \& Seppälä 1987: 147).

On the basis of observations on fell summits and from places below the oroarctic forest limit, King and Seppälä (1987) proposed that the distribution of permafrost in Finnish Lapland extends much beyond the palsa region and that permafrost occurs widely on the barren fell tops above the tree line (Fig. 1). In the forest zone in the valleys permafrost does not exist outside the mires, however. Our southernmost observations are from Kaunispää $\left(68^{\circ} 26^{\prime} N\right)$, and the Broadcasting Co's report is from Ylläs $\left(67^{\circ} 34^{\prime} N\right)$. Barren fell tops occur further south as well, but no measurements for them are yet available. Plans have been made to study the distribution of permafrost in more detail.

\section{Cave ice}

Kejonen et al. (1991) found massive permanent ice in a cave on Korkia-Maura island in Lake Inari (Fig. 1). Ice covering the bottom of the cave is $9 \mathrm{~m}$ long and $3 \mathrm{~m}$ wide and more than $2 \mathrm{~m}$ thick. The seasonal variation of the ice thickness is about $50 \mathrm{~cm}$. In southern and central Finland the same authors (Kejonen et al. 1991) found several caves with patterned ground at their base, but no caves with permafrost, though seasonal icing is a common feature.

\section{FACTORS FAVOURABLE FOR PERMA- FROST FORMATION}

\section{Temperature}

For permafrost formation the mean annual air temperature (MAAT) should in general be below zero degrees centigrade. In the palsa region of Finnish Lapland the MAAT is below $-1{ }^{\circ} \mathrm{C}$ and close to $-2^{\circ} \mathrm{C}$ (Kolkki 1965). Meteorological observations further show that in several places in northern Finland the MAAT often is about $-3^{\circ} \mathrm{C}$ (Seppälä 1976, Seppälä \& Hassinen 1997), which is sufficient for permafrost formation. The cold areas are the interior and the mountainous region in the NW corner, while the warming influence of the Barents Sea and Lake Inari causes higher MAAT in the NE corner.

The mean dates of first soil frost formation are between 15 and 25 October (Soveri \& Varjo 1977). The coldest months are January and February when the minimum temperatures often fall below $-40^{\circ} \mathrm{C}$. Seasonal thawing begins in May when the mean monthly air temperatures (MMAT) rise above $0^{\circ} \mathrm{C}$, but considerable snow remains on the ground. Snow melt in the valleys continues throughout May and lakes at higher altitudes stay frozen until mid-June (King \& Seppälä 1988). In 1997 Kilpisjärvi did not become free of ice until 1 July. July is the warmest month with MMAT between $+12^{\circ} \mathrm{C}$ and $+14^{\circ} \mathrm{C}$ and maximum temperatures about $+30^{\circ} \mathrm{C}$.

The freeze indices were calculated for several meteorological stations by summing the daily mean temperatures for days when the mean temperature was below $0^{\circ} \mathrm{C}$ (Seppälä \& Hassinen 1997). In the palsa region (Fig. 1) of Finland the mean freeze index was exceeded -2000 in the years 1980-1991 and the annual range was from -1516 to -2737 (Seppälä \& Hassinen 1997).

In considering the temperature statistics it is important to remember that there is no official meteorological station just at the palsa mire and that the standard meteorological observations are made in a shelter $2 \mathrm{~m}$ above the ground surface. Since frost is a ground feature we really should know the ground temperatures. Certainly these are measured at some stations, but again away from the permafrost sites. Local temperatures are particularly important because they are affected by several other factors such as topography and snow depth of the region. In many places with low air temperatures no permafrost is observed. In correlating permafrost formation and air temperatures we therefore need to exercise a good deal of caution. 


\section{Topography}

Meteorological stations are mainly located in the valleys and their readings do not decribe conditions on the fell summits. Inversion is a very common feature in winter time, and temperatures are often $10^{\circ} \mathrm{C}$ higher at the summits than in the valleys some hundreds of metres beneath (Helimäki 1974; Huovila 1974). When it is very cold $\left(-40\right.$ to $\left.-45^{\circ} \mathrm{C}\right)$ at the Kevo station (Fig. 1) in the valley bottom, the summit temperatures $250 \mathrm{~m}$ above may be as much as $20^{\circ} \mathrm{C}$ higher (Tabuchi \& Hara 1992). Cold air is heavy and sinks down the slopes to the basins and valleys below. This means that the thermal gradient of $0.6^{\circ} \mathrm{C} / 100 \mathrm{~m}$, which is for free atmosphere rising up from the earth's surface cannot be used for approximation of MAAT in mountainous country. For example, on a palsa which lies c. 220 $\mathrm{m}$ higher than the Kevo meteorological station the minimum temperature in 1992-93 was $-23.4^{\circ} \mathrm{C}$ on the uncovered palsa surface and $-34.9^{\circ} \mathrm{C}$ at the station. The higher temperature cannot, however, be interpreted tomean that permafrost formation on the fell summits would be prevented. The air temperatures there are still cold enough and, because there often is no insulating snow cover, the ground may cool and the frost penetrate much deeper than in the snowcovered valley bottoms (King \& Seppälä 1988).

\section{Precipitation and snow depth}

If permafrost is to form in this type of marginal region, precipitation should not be high because liquid water transports latent energy well and weakens the insulating capability of peat by increasing its thermal conductivity. High precipitation in winter, on the other hand, increases snow depth and snow is a very good insulater. Initiation of palsa requires a thin snow cover as has been experimentally proved (Seppälä 1982a, 1986, 1990, 1995).

As recorded at the meteorological stations in valleys with forests annual precipitation in Finnish Lapland ranges between 300 and $400 \mathrm{~mm}$.
February-May is a period of low precipitation and maxima occur in July-August. More than $50 \%$ of the annual total precipitation is recorded during June-September (Helimäki 1966), which is the thaw season. About $30-40 \%$ of the annual precipitation is in the form of snow. The average maximum thickness of the snow cover is 60-80 $\mathrm{cm}$ and normally is reached in March or April.

In the summit areas of fells, the snow cover is only $5 \mathrm{~cm}$ or less and may have disappeared completely by the end of February (Kallio et al 1969). Careful measurements of snow depth on a palsa mire have shown that even the local differences in snow depth are very great: the palsa surfaces are uncovered for most of the winter while thick layers of wind-deposited snow cover the steep sides, preventing the frost from penetrating deep in the peat layers (Seppälä 1994). Under a 1-m-thick snow cover temperature is constant (about $0^{\circ} \mathrm{C}$ ) through the winter and there is no opportunity for thick frost formation. Jeckel (1988) confirmed the existence of permafrost at Mt. Saana (Fig. 1) by measuring the bottom temperatures of the winter snow cover, which must be lower than $-3^{\circ} \mathrm{C}$ for permafrost formation (cf. Haeberli 1973).

\section{Soil characteristics}

Frost formation in soils depends upon their physical properties: grain size, mineralogy, texture, porosity, thermal conductivity, capillarity, humus content (see Washburn 1979; Williams \& Smith 1989). Together these characteristics determine the frost sensitivity of the soil. The common soils in northern Finland are till, gravel, sand, silt and peat. All these soils freeze, but silty tills and silt and peat are particularly frost active. So far, permafrost has not been found in superficial mineral soils but only in silty till and silt beneath the palsas. Probably the seasonal frost, which can penetrate more than $3 \mathrm{~m}$ in gravelly till as at Kevo (e.g. Seppälä 1976), is not cold enough to survive unmelted in the summer heat. The soil cover on fells tends to be very thin. Some eskers and glaciofluvial deltas 


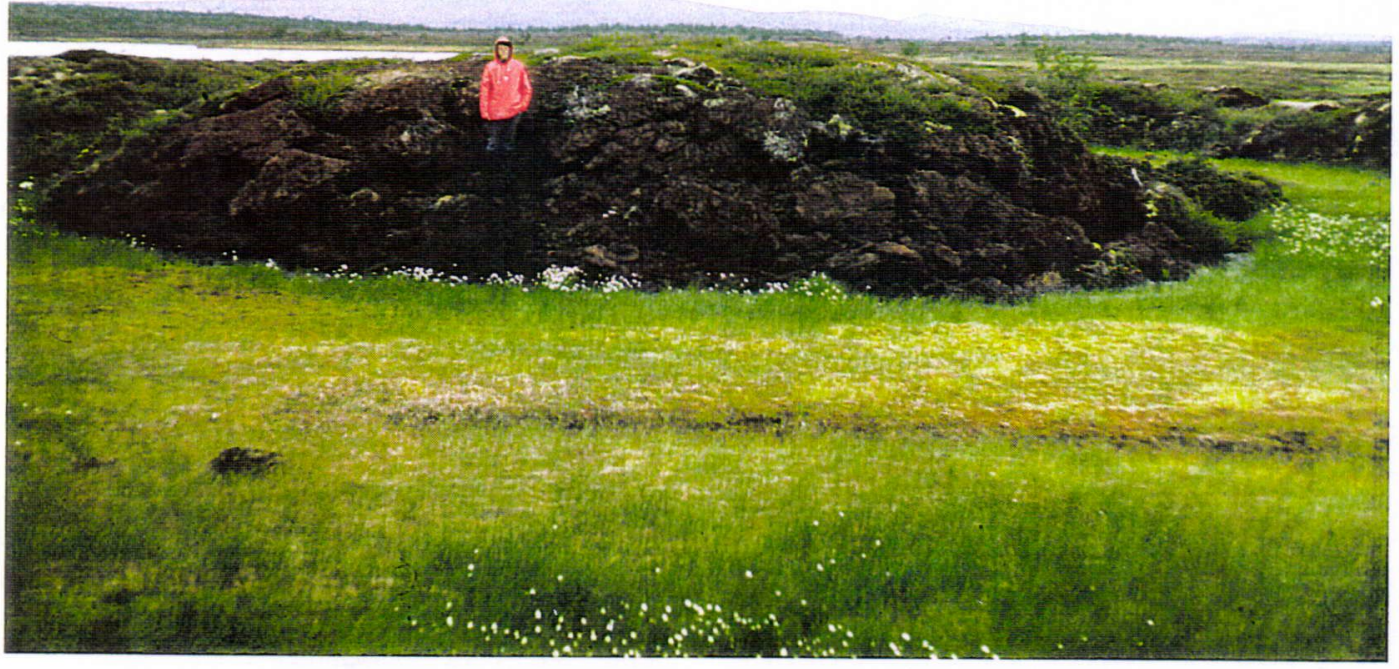

Fig. 2. A wind eroded old palsa to the east of Ailigas fell, Utsjoki, Finnish Lapland. July, 1972.

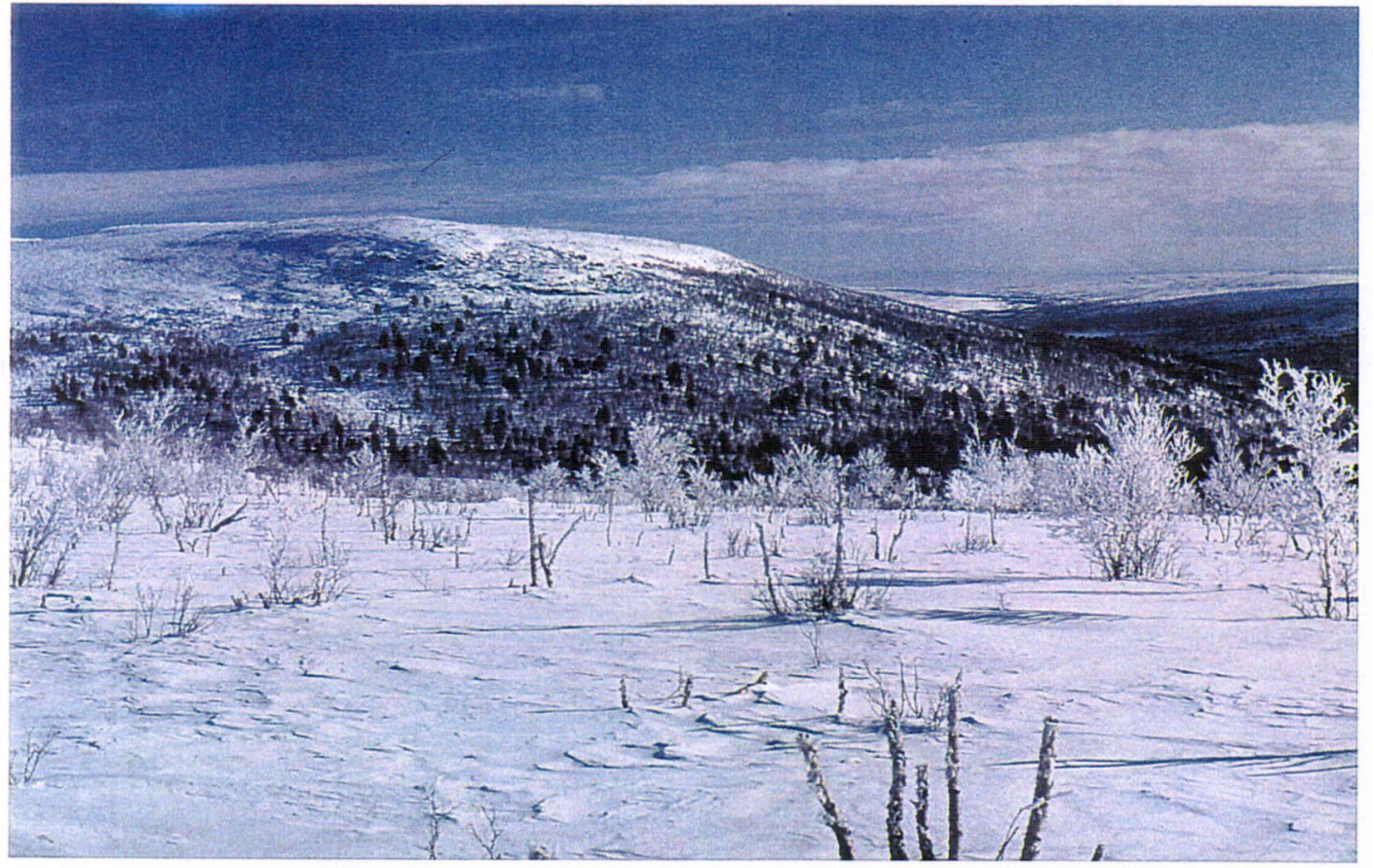

Fig. 3. Jesnalvaara fell, Utsjoki. A typical landscape from the northernmost Finland. Permafrost is located on the fell top above the tree line. No permafrost is found in the Utsjoki river valley with pine forest on the left. On the foreground scattered remains of birches damaged by a moth (Epirita autumnata). March, 1985. 
exist in barren summit areas and they probably contain some permafrost, but no records are available. Gravel is a highly porous material containing a lot of air and if the ground water has frozen a thick layer of dry gravel on top may preserve the frost. A layer of dry peat is the best protection for frozen ground.

Soil moisture is the critical factor for frost heave and for many frost features such as palsas, gelifluction lobes and patterned grounds. Water saturated soil together with cold is needed for their formation. Dry soil does not support the formation of frost features. However it needs to be remembered that not all periglacial features require permafrost for their development; deep seasonal freezing is enough for frost heave and mass wasting and frost sorting. Thus, not all active patterned grounds point to the existence of permafrost. Palsas are true permafrost features in the discontinuous permafrost zone.

\section{VEGETATION AS AN INDICATOR}

Plants and especially plants that are conspicuous by their absence, are useful permafrost indicators. In Lapland it seems to be a rule that large trees do not grow on permafrost: the permafrost area in general lies above the timber line and is indicated by low and medium heath vegetation (King \& Seppälä 1987). In western Finnish Lapland the forest limit lies between 400 and 500 $\mathrm{m}$ above sea level; in Kilpisjärvi (NW most corner) it rises to $600 \mathrm{~m}$ a.s.l. and then drops on north-facing slopes in northernmost Finland to about $100 \mathrm{~m}$ a.s.l. (King \& Seppälä 1987: 186). The timber line is somewhat above the forest limit.

Heaths extend above the forest limit. The lower heathlands are dominated by shrubs such as Betula nana, Vaccinium myrtillus and Empetrum hermaphroditum, and the fell summits by Salix herbacea, Empetrum and alpine grasses with lichens and mosses (King \& Seppälä 1987: 186). A good correlation is found between snow depth and type of vegetation (Clark et al. 1985). Plants that require a certain protection of snow cover do not survive without it and this means that, for example, Vaccinium myrtillus heaths usually carry $80 \mathrm{~cm}$ snow at maximum, and that is too much for permafrost formation in Finnish Lapland. Diapencia lapponica is a good indicator of thin snow cover and marks a windswept heath with less than $20 \mathrm{~cm}$ snow. Snow depth is the most critical factor for permafrost formation (Seppälä 1982a; King 1986), and study of the vegetation allows the amount to be estimated also in the summertime. For example, Betula nana and Juniperus communis do not grow higher than the maximum snow depth because all branches rising above the snow surface would be frost dried in the strong spring sunshine.

When permafrost forms on mires, the previous vegetation will die and new species will take over. This was noticed during the palsa experiment (Seppälä 1982a; 1995) and during the winter 1984-85 when new palsa embryos were formed in Skallovarri (Seppälä 1990). Sphagnum species growing on very wet surfaces suffered and died when permanent frost was formed and the mire surface was raised above the normal level by the frost heave.

Vegetation also gives us the first signs of deflation which is indicative of thin snow cover and the possibility of deep frost penetration.

\section{THE FUTURE OF PERMAFROST IN LAPLAND}

Although northern Lapland is cold enough for permafrost formation, precipitation normally, is too high. Strong winds will blow snow away from places with low vegetation such as open mires and treeless fell summits, creating favourable conditions for permafrost formation.

At the moment the permafrost is in fairly good balance with the environmental conditions, which means that old palsas are collapsing and melting at the same rate as fresh features are forming. If the conditions were to change towards increasing snow depth and/or wetter summers the number of palsas would decrease. Increasing amounts of snow mean that the palsa 
core cannot store enough cold to survive the summer. Summer precipitation, in turn, increases the thermal conductivity of the insulating surface peat and the active layer on palsas will become thicker. Both trends are fatal for palsas.

Deep permafrost in bedrock requires hundreds, probably even thousands of years to react to climatic change.

\section{PROPOSALS FOR PERMAFROST STUDIES}

Plans have been put forward for deep drilling in the summit areas of fells to monitor bedrock temperatures and predict probable changes. We need considerable background information before we are able to say anything of future developments. New meteorological recordings, especially measurements of ground surface temperatures on fell summits, should be pursued.
To track their development we need systematic palsa studies. A palsa inventory has been under preparation for years already and will be published as a map covering the whole of Finnish Lapland.

New techniques such as ground radar and geoelectric soundings are needed to continue the permafrost studies in Lapland and to produce an overall picture of the permafrost conditions. Finland is very well located, just at the border of the discontinuous permafrost region, and it has a better infrastructure in the far north than do many other countries. These favourable features should be exploited in the interest of subarctic studies. The study sites are easily accessible at reasonable cost, allowing scientifically sound studies of international interest to be carried out.

ACKNOWLEDGEMENTS: Mrs Key Ahonen kindly improved the language of the English manuscript. 


\section{REFERENCES}

Åhman, R. (1977) Palsar i Nordnorge. (Summary: Palsas in northern Norway.) Meddelanden från Lunds Universitets Geografiska Institution 78, $165 \mathrm{p}$.

Clark, M.J., Gurnell, A.M., Milton, E.J., Seppälä, M. \& Kyöstilä, M. (1985) Remotely-sensed vegetation classification as a snow depth indicator for hydrological analysis in sub-arctic Finland. Fennia 163, 195-216.

Fogelberg, P. \& Seppälä, M. (1978) General geomorphological map 1:1 000 000. Atlas of Finland Folio 122 (1986): 3-4.

Haeberli, W. (1973) Die Basis-Temperatur der winterlichen Schneedecke als möglicher Indikator für die Verbreitung von Permafrost in den Alpen. Zeitschrift der Gletscherkunde und Glazialgeologie 9, 221-227.

Hänninen, P. (1995) Pudasjärvellä Suomen eteläisin "palsa". Geologi 1995(6), 75-78.

Helimäki, U.I. (1966) Tables and maps of precipitation in Finland, 1931-60. Supplement to the Meteorological Yearbook of Finland 66(2), 22 p.

Huovila, S. (1974) Lämpötilojen vaihtelurajat Pohjois-Suomessa. (Summary: Temperature range in northern Finland.) Rovaniemi, Lapin Ilmastokirja - Climate of Lapland, 18-22.

Jeckel, P.-P. (1988) Permafrost and its altitudinal zonation in N. Lapland. Permafrost Fifth International Conference, Proceedings 1: 170-175.

Kallio, P., Laine, U. \& Mäkinen, Y. (1969) Vascular flora of Inari Lapland. 1. Introduction and Lycopodiaceae - Polypodiaceae. Reports from the Kevo Subarctic Research Station 5, 108 p.

Kejonen, A., Kielosto, S. \& Salonen, V.-P. (1991) Ikiroutaa ja kuviomaita Suomen luolissa. (Summary: Permafrost and patterned grounds in Finnish caves.) Geologi 1991(7), 135-141.

King, L. (1982) Qualitative and quantitative Erfassung von Permafrost in Tarfala (Schwedish Lappland) und Jotenheimen (Norwegen) mit hilfe geoelektrischer Sondierungen. Zeitschrift für Geomorphologie, Suppelement-Band 43, 139-160.

King, L. (1983) High mountain permafrost in Scandinavia. Permafrost: Fouth International Conference, Proceedings, 612-617.

King, L. (1984) Permafrost in Skandinavien. Untersuchungsergebnisse as Lappland, Jotenheimen und Dovre/Rondane. Heidelberger Geographische Arbeiten $76,174 \mathrm{p}$.
King, L. (1986) Zonation and ecology of high mountain permafrost in Scandinavia. Geografiska Annaler 68A, 131-139.

King, L. \& Seppälä, M. (1987) Permafrost thickness and distribution in Finnish Lapland - Results of geoelectrical soundings. Polarforschung 57, 127147.

King, L. \& Seppälä, M. (1988) Permafrost sites in Finnish Lapland and their environment. Occurrences de pergelisol en Lapponie Finlandaise. Permafrost Fifth International Conference, Proceedings $1,183-188$.

Kolkki, O. (1965) Tables and maps of temperature in Finland during 1931-60. Supplement to the Meteorological Yearbook of Finland 65(1a), 42 p.

Schenk, E. (1966) Zur Entstehung der Strangmoore und Aapamoore der Arktis und Subarktis. Zeitschrift für Geomorphologie N.F. 10, 345-368.

Schenk, E. (1970) On the string formation in the aapa moors and raised bogs in Finland. Ecology of the subarctic regions. Proceedings of the Helsinki Symposium. UNESCO; Paris. 335-342.

Seppälä, M. (1976) Periglacial character of the climate of the Kevo region (Finnish Lapland) on the basis of meteorological observations 1962-71. Reports from the Kevo Subarctic Research Station 13, 1-11.

Seppälä, M. (1982a) An experimental study of the formation of palsas. Proceedings 4th Canadian Permafrost Conference, 36-42.

Seppälä, M. (1982b) Palsarnas periodiska avsmältning i Finska Lappland. Geografisk Tidsskrift 82, 3942.

Seppälä, M. (1983) Seasonal thawing of palsas in Finnish Lapland. Permafrost Fourth International Conference, Proceedings, 1127-1132.

Seppälä, M. (1986) The origin of palsas. Geografiska Annaler 68A, 141-147.

Seppälä, M. (1988) Palsas and related forms. In: M.J. Clark (ed.): Advances in periglacial geomorphology. John Wiley, Chichester, 247-278.

Seppälä, M. (1990) Depth of snow and frost on a palsa mire, Finnish Lapland. Geografiska Annaler 72A, 191-201.

Seppälä, M. (1994) Snow depth controls palsa growth. Permafrost and Periglacial Processes 5, 283-288.

Seppälä, M. (1995) How to make a palsa: a field experiment on permafrost formation. Zeitschrift für Geomorphologie, Supplement-Band 99, 91-96.

Seppälä, M. \& Hassinen, S. (1997) Freeze-thaw indices in northernmost Fennoscandia according to meteorological observations, 1980-1991. In: Sven Knutsson (ed.): Ground Freezing 97. Frost action 
in soils. Proceedings of the International Symposium on Ground Freezing and Frost Action in Soils, Luleå. Balkema, Rotterdam, 153-160.

Seppälä, M. \& Koutaniemi, L. (1985) Formation of a string and pool topography as expressed by morphology, stratigraphy and current processes on a mire in Kuusamo, Finland. Boreas 14, 287-309.

Soveri, J. \& Varjo, M. (1977) Roudan muodostumisesta ja esiintymisestä Suomessa vuosina 19551975. (Summary: On the formation and occurrence of soil frost in Finland 1955 to 1975.) Publications
Water Research Institute, National Board of Waters, Finland 20, 66 p.

Tabuchi, H. \& Hara, Y. (1992) Block fields and sorted polygons in Finnish Lapland (Summary in English). Geographical Review Japan 65(2), 105-113.

Washburn, A.L. (1979) Geocryology: A survey of periglacial processes and environments. Edward Arnold, London, $406 \mathrm{p}$.

Williams, P.J. \& Smith, M.W. (1989) The frozen earth. Fundamentals of geocryology. Cambridge University Press, England, 306 p. 